\title{
Expression of proteins (CLIC1 and PSMD7) in breast cancer cells with treatment by nano oleuropein of olive fruit using comparative proteomics
}

\author{
Mohammad Zaefizadeh ${ }^{1}$ \\ Traditional medicine and hydrotherapy research center, Ardabil \\ University of medical sciences, Daneshgah st. Ardabil, Ira \\ Kamelia Mobasheri \\ Department of Biology, Ardabil branch, Islamic Azad University, \\ Rezazadeh street, Basij Square, Ardabil, Iran \\ Sayyara Ibadullayeva \\ Institute of Botany, Azerbaijan National Academy of Sciences, \\ Badamdar highway 40, Baku, AZ1004, Azerbaijan \\ Amin Mohsenzadeh \\ Department of Microbiology, Faculty of Science, Ardabil branch, \\ Islamic Azad University, Rezazadeh street. Basij Square, Ardabil, \\ Iran \\ Hoda Sabati \\ Biotechnology and Biological Science Research Center, Faculty \\ of Science, Shahid Chamran University of Ahvaz, Golestan street, \\ Ahvaz, Iran
}

\begin{abstract}
Breast cancer is the most common type of cancer which leads to many deaths among women. Olive because of its antioxidant compounds is considered as a candidate in controlling and prevention of cancer. In this study the impact of Nano oleuropein of olive in densities, namely $0 \mathrm{ppm}, 300 \mathrm{ppm}$ and $600 \mathrm{ppm}$ treatment on the protein profile in $M C F-7$ cell line using two-dimensional electrophoresis and MALDI-TOFTOF was examined. Results of changes in expressed protein spots showed that among 317 spots, four proteins include CLIC1, HSPB1, PSMD7, and SULT1A2 had significant differential change which were confirmed with level less than $1 \%$ in Masscot. These proteins are important factors in the anti-proliferative pathway and induction of apoptosis pathway. Therefore, by inducing the incensement of expression of (PSMD7 and CLIC1) proteins by oleuropein treatment, cancer cells of $M C F$ 7 with the help of anti-proliferation and apoptosis mechanisms play a major role in their containment and a significant reduction in expression (SULT1A2 and $H S P B 1)$ as a way to support the induction of apoptosis pathway is presented by the oleuropein. Oleuropein ensures further investigations to prove its utility in preventing/treating breast cancer.
\end{abstract}

Key Words: Duncan test, electrophoresis, LCR test, MCF-7, MALDITOF-TOF, spot

\section{INTRODUCTION}

Cancer is a disease of uncontrolled cell growth and spread, which cells do not respond to the checkpoints leading to tumor growth and metastasis. Among cancer treatment techniques, chemotherapy does not specifically target drugs to cancerous areas, thus exposing normal cells to negative side effects. In addition, large doses are required owing to their rapid removal and non-specific distribution [Schättler, Ledzewicz, 2015; De Matteis et al., 2018]. Due to the adverse effects of chemotherapy, the goal of Nanomedicine is to find cost-effective molecules that have high specificity and sensitivity in cancerous cells. Breast cancer is the most common cancer diagnosed in women and the second leading cause of death from cancer among them [Di Wu et al., 2017]. The main cause of cancer is defective proteins; therefore, they are important clues for diagnosis and treatment of the cancer. In addition, proteins are primary targets for many drugs and are considered the primary basis for the design of drugs. Devising the therapeutic interventions to target cancer stem cells would be useful in increasing patients' survival rates [Dalby et al., 2020]. Phytopolyphenols are integral part of the human diet. They have been also used worldwide in traditional medicine for thousands of years for their anti-bacterial, anti-viral, anti-inflammatory, anti-allergic, and anti-thrombotic properties. The effects of phyto-polyphenols are usually pleiotropic, and many of these compounds have proven anti-carcinogenic actions manifested by suppression of cancer cell transformation, differentiation, proliferation and invasiveness, angiogenesis and induction of apoptosis. The suppressing effects of the polyphenols on breast cancer initiation and cell growth are demonstrated in multiple in vitro and in vivo systems [Avtanski et al., 2018]. Oleuropein (Ole) is a phenolic compound presents in fruits, olive leaves and oil. This molecule has been shown to have favorable effects on several human pathological conditions. In particular, recent studies have provided evidence that Ole exhibits preventive effects on different types of human tumors. Studies undertaken to elucidate the specific

1'E-mail: mzaefi@iauardabil.ac.ir

Received 08.11.2021; Received in revised form 19.11.2021; Accepted 25.11.2021 
mechanisms underlying these effects have shown that this molecule may thwart several key steps of malignant progression, including tumor cell proliferation, survival, angiogenesis, invasion and metastasis, by modulating the expression and activity of several growth factors, cytokines, adhesion molecules and enzymes involved in these processes [Leto et al., 2020; Alam et al., 2018; Groh et al., 2013]. Nano molecules have become a promising strategy for anti-cancer treatment due to their inherent properties and they are designed to assist therapeutic agents to pass through biologic barriers, to mediate molecular interactions, and to identify molecular changes [Sutradhar, Amin, 2014]. Genomic and transcriptomic profiles of breast cancer have been well established; however, the proteomic contribution to these profiles has yet to be elucidated and more studies need to be done in this field [Zeidan et al., 2015; Doll et al., 2019]. Proteomics mainly examines the structure and function of the proteome, isoforms, structural changes, Post-transcription and translation changes, phosphorylation and glycosylation, interaction with other proteins and drugs [Bludau, Aebersold, 2020; Tyanova, Cox, 2018; Doll et al., 2019]. Scientists design biological network optimization algorithm for diseases detection such as cancer. Applications of proteomics are investigation inhibition of cancer cells, anti-proliferation effects and apoptosis [Haymond et al., 2019; Gao et al., 2017; Khurshid et al., 2020]. The aim of this study was to investigate the inhibitory effect of Nano Oleuropein treatment on $M C F-7$ cell line growth by inducing and changing the differential protein expression using 2-dimensional electrophoresis.

\section{MATERIAL AND METHODS}

Specifications of cell line used in the experiment are $M C F-7$ breast tissue epithelial cell lines. $M C F-7$ cells were cultured. Extraction of oleuropein canned variety olive fruit seeds were dried by liofilizator. The standard oleuropein (Sigma) was separated and purified using preparative HPLC compared with retention time (RT). Infrared spectroscopy is commonly used to analyze and identify materials and examined using FTIR spectrum. Approximate effect range of oleuropein on $M C F-7$ cells was determined. Protein extraction obtained from homogenized cells. One dimensional electrophoresis or isoelectric focusing (IEF) or Electrofocusing was performed using (GeheaithcareEttanIPGphar 3 Amersham Protein IEF) device. For Strips equilibration of electrophoresis in the second dimension after isoelectric focusing (IEF), gel strips were placed on an equilibration SDS-PAGE solution. Placement of strips on SDS-PAGE gel performed. After electrophoresis, the gel was separated from the glass mould and was stained using Coomassie Blue G250 method [Arndt et al., 2018]. All stages of the 2-dimensional electrophoresis and isolation of the desired spots were carried out in the equipped Laboratories for the National Center for Biotechnology and Genetic Engineering, Iran. In differential protein spots selection procedure, all spots were encoded on the gels using Melani Software. The area of each spot was calculated and those differential spots with similar area were selected three times and were later sent to Ware University, UK for MS evaluation after cutting two-dimensional gel using MALDI TOFTOF method via SinaClon. After examining the pieces, MSs with higher frequency were determined and the molecular weight of obtained pieces was analyzed through matching in Data Base using Masscot and significance level and score were determined.

Statistical analysis. Least Significant Ranges (LSR) test was used in SPSS statistical software version 25 (SPSS Inc., Chicago, IL, USA) for MTT data compare the difference among groups (concentration) in terms of OD at $\mathrm{P}$-value $\leq 0.1 \%$. Priority analysis of concentrations in terms OD levels was carried out using Duncan test. After being cut, the spots were sent to Ware University in UK via SinaClon for MS evaluation. Level of significance and score were specified and announced through Masscot Data Base.

\section{RESULTS AND DISCUSSION}

The results of ANOVA for different concentrations of oleuropein $(10000,2500,625,156.25,39.06,9.76$, $2.44,0.61,0.152 \mu \mathrm{l} / \mathrm{ml})$ in terms of growth inhibition of MCF-7 human breast cancer cells after 24, 48, 72 showed that there is a significant difference between different oleuropein concentrations (P-value $\leq 0.001$ ) (Fig. 1). Oleuropein concentrations in Duncan method at $\mathrm{P}$-value of $5 \%$ indicated that the highest inhibition of cancer cells occurs in $10000 \mu \mathrm{g} / \mathrm{ml}$. However, 0.625 , 0.39 to $0.152 \mu \mathrm{g} / \mathrm{ml}$. concentrations induced the least growth inhibition. This means that the oleuropein concentrations act differently in terms of inhibition of MCF-7 cancer cells growth. However, the above concentration was not statistically different from 2500.625 and $156.25 \mu \mathrm{g} / \mathrm{ml}$ concentrations. 39.06 to $0.152 \mu \mathrm{g} / \mathrm{ml}$ treatments had the least growth inhibition and were grouped in Group D in the sense that there was no statistical difference between these concentrations in terms of inhibiting cancer cells growth compared to the 


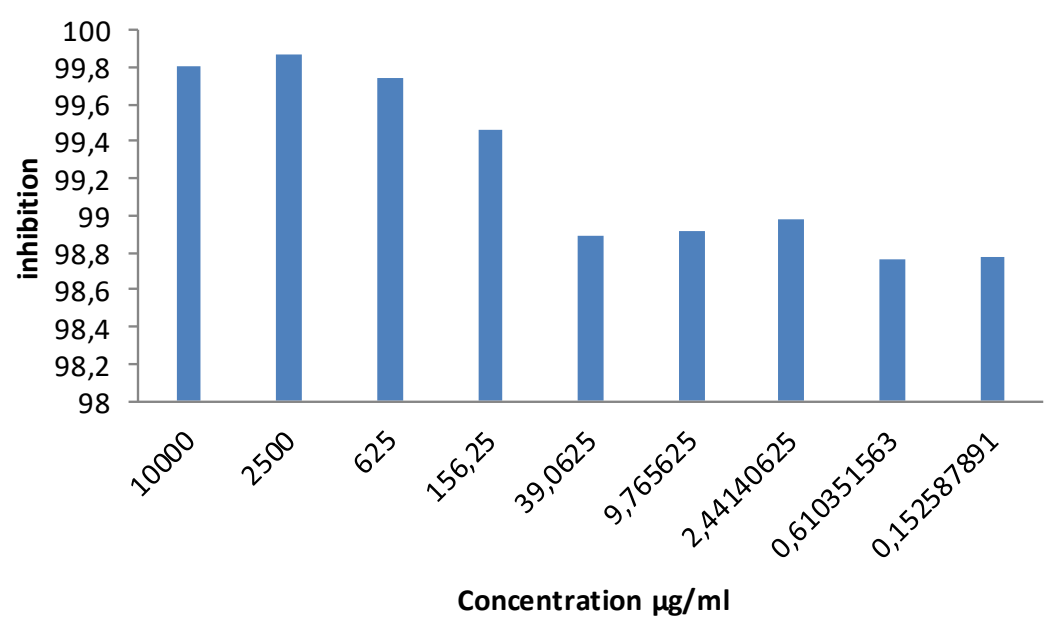

Figure 1. Results of comparing average inhibition growth of cancer cells in different Oleuropein concentrations after 24 hours of treatment using Duncan method at p-value of 5\%.

other concentrations.

The results of ANOVA for different Nano Oleuropein concentrations $(10000,2500,625,156.25,39.06,9.76$, $2.44,0.61,0.152 \mu \mathrm{g} / \mathrm{ml})$ in terms of growth inhibition of $M C F-7$ human breast cancer cells after 24 hours showed that there is a significant difference between different Nano oleuropein concentrations (P-value $\leq 0.001)$. Data not shown. The result of comparing average growth inhibition (after 24 hours) induced by the Nano oleuropein concentrations in Duncan method at $\mathrm{P}$-value of $5 \%$ indicated that the highest inhibition of cancer cells occurs when the $10000 \mu \mathrm{g} / \mathrm{ml}$ oleuropein concentration was used. Microscopic images "invert" in normal conditions and concentrations of different treatments and Nano oleuropein. Spot of Moldi TOF TOF MS identified 317 spots, 2 spots, to No. 1, 2, 3, 4, were significant differences in the expression.

The (CLIC1_ HUMAN) protein with high score $(\mathrm{P}<0.05)$ was diagnosed at during alignment pieces in Masscot online data base. This protein is a human protein $(\mathrm{PI}=5.09)$, the molecular weight of which was estimated $\left(\mathrm{M}_{\mathrm{r}}=27248\right)$ Spot No. 3 (No. 13, Fig. $2,3,4)$. The sequence coverage rate of this protein was $58 \%$. This protein was upregulated in 600PPM Oleuropein treatment compared with 300PPM and the control treatments (Fig. 3, 4); therefore, it seems that Oleuropein up-regulated this protein. In Elaine Masscot of pieces of high molecular weight, this protein was identified as (PSMD7 HUMAN) with score of (343) at $\mathrm{P}<0.05$. This protein is a human protein $(\mathrm{PI}=6.29$ ), the molecular weight of which was estimated $\left(\mathrm{M}_{\mathrm{r}}=\right.$ 37060). The sequence coverage rate of this protein was $79 \%$. This protein was upregulated in 600PPM

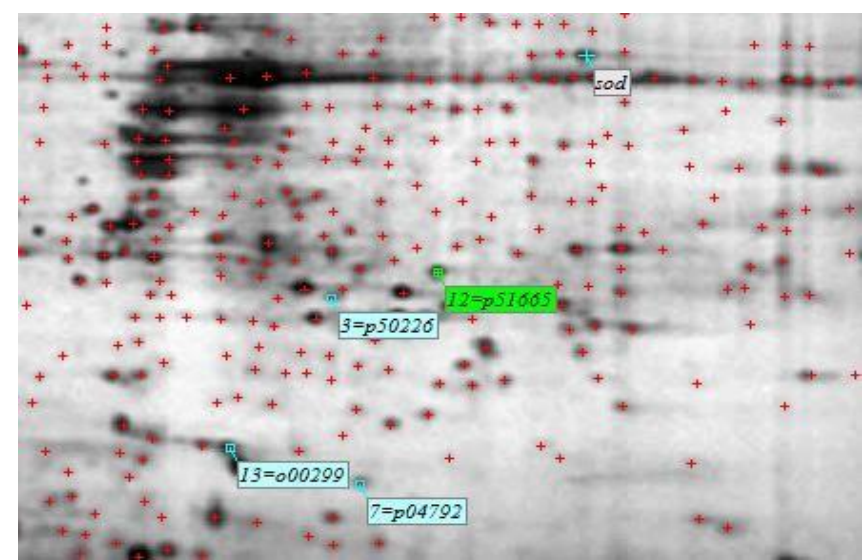

Figure 2. The two-dimensional electrophoresis page for total 317 spots and 4 differentially spots identified by Maldi Tof-Tof method.

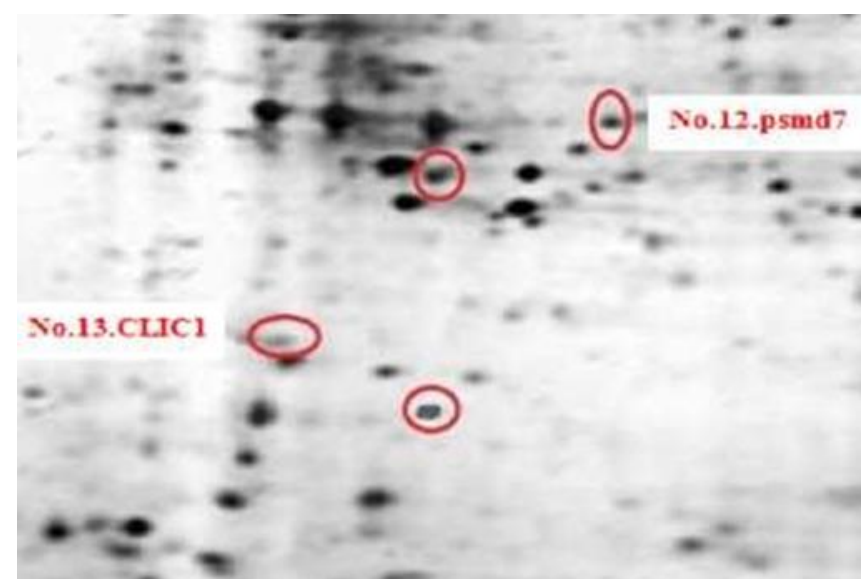

Note: Spot No 13 an spot No 12 were identified CLIC1 and PSMD7, respectively.

Figure 3. The two-dimensional electrophoresis page of differential protein spots in control (control, 0PPM Oleuropein ). 


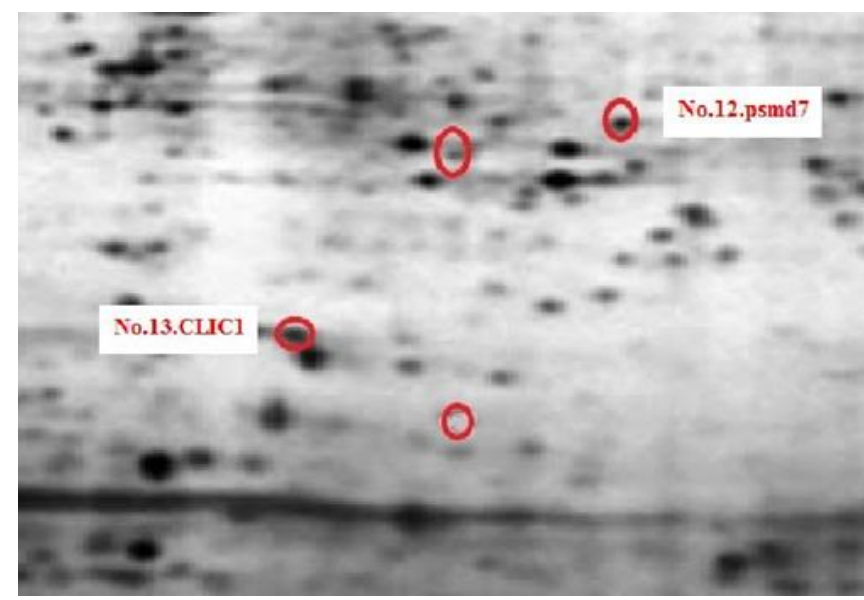

Note: Spot No 13 an spot No 12 were identified CLIC1 and PSMD7, respectively

Figure 4. The two-dimensional electrophoresis page of differential protein spots in treatment with Oleuropein (concentration of 300 PPM).

oleuropein treatment compared with 300PPM and control treatments (Fig. 3, 4); therefore, it seems that oleuropein up-regulated this protein. S1- S2 -S3: The above proteins were upregulated in $\mathrm{s} 2$ and $\mathrm{s} 3$ samples compared to S1 samples.

Recently, the anti-cancer impacts of different natural components have become the focus of an interesting deal of attention in cancer researches, owing mainly to their potential in prevention of different types of cancer [Dalby et al., 2020; Leto et al., 2020]. Breast cancer is the most common type of cancer which leads to many deaths among women. As any kind of metastatic disease, few curative therapies currently exist for breast cancer treatment which are more palliative and sustaining. Relapse and metastases happen frequently and in general, are unresponsive to conventional treatments. Therefore, more efficient approaches are required to cure breast cancer and the identification of bioactive compounds with the ability to suppress breast cancer growth promises to be an effective strategy for the therapy of this disease [Avtanski et al., 2018; Khurshid et al., 2020; Asgharzade et al., 2020]. In the present study the impact of Nano oleuropein obtained from olive was investigated on the prevention and treatment of breast cancer. The results showed that Nano oleuropein could inhibit the growth of cancer cells by $99 \%$ and $2500 \mu \mathrm{g} / \mathrm{ml}$ was the most effective concentration on the inhibition rate although it was significantly different from the $10000 \mu \mathrm{g} / \mathrm{ml}$ concentration. so that even very low Nano oleuropein concentration of $0.152 \mu \mathrm{g} / \mathrm{ml}$ could inhibit the growth of cancer cells by $98.8 \%$ in vitro environment. Growth inhibition of $M C F-7$ cells due to the cell cycle arrest in the G0/G1 phase was shown when the cells were treated with Nano oleuropein. When cells were treated for changed concentration ranges, the cell cycle arrest at G1 phase was evident, accompanying a decrease in G2/M phase when compared with the untreated control cells. From this result we suggest that apoptotic cell death of $M C F-7$ cells after Nano oleuropein treatment was accompanied with the block of cell cycle at G1 phase [Zeidan et al., 2015; Shamshoum et al., 2017]. Also the results confirm that the cytotoxicity of Nano oleuropein on cancer cells depends on the Nano oleuropein concentration. The selective influence of Nano oleuropein which allows it to differentiate between cancer and normal cells renders it a very efficient bioactive agent in the treatment of hypertrophic breast cells and in preventing the transformation of them into cancerous cells. So Nano oleuropein treatment could be useful both for the prevention of tumor progression and/or therapy, either alone or in combination with conventional preventive or therapeutic agents for the prevention and/or treatment of breast cancer [Abtin et al., 2018]. These findings were consistent with some of studies [Aktas et al., 2020; Asgharzade et al., 2020; Shamshoum et al., 2017]. Oleuropein played an inhibitory role in LN-18 cell growth in glioblastoma cell lines as well as TF-1a (erythroleukemia) and cell lines derived from human tumors [Han et al., 2009]. Previous studies reported that oleuropein is a powerful phenolic compound in decreasing viability of breast cancer cells. Another study showed that oleuropein played a role in the death of breast cancer cells in the micro-molar. They also showed that oleuropein was cytotoxic to breast cancer cells, in which HER2 was upregulated [Abtin et al., 2018; Lu et al., 2021]. S. Bayat reported that Oleuropein reduced viability of $M C F-7$ cancer cells [Bayat et al., 2019]. Oleuropein has anti-proliferative property and has been used at micromolar amounts against cancer cell lines and has inhibitory effects on breast cancer cells $(M C F-7)$. Also oleuropein is an antioxidant that can inhibit some tumor suppressor genes caused by cancer cells by reducing the oxidant structure as well as $\mathrm{CpG}$ demethylation [Aktas et al., 2020; Asgharzade et al., 2020]. Oleuropein was suggested to prevent the transformation of normal cells into cancer cells due to the probability of its prevention to oxidative stress in normal breast cells. It has been suggested that consumption of olive oil, which is particularly rich in antioxidants, such as oleuropein, 
may provide protection against breast cancer by inhibiting oxidative stress. The overall evidence from in vitro assays, animal and human studies support the antioxidant effect of oleuropein [Lu et al., 2021]. It was confirmed in our experiment that oleuropein played an inhibitory role for breast cancer cells and inhibition of second apoptosis induction pathway is through the oleuropein treatment. Oleuropein has anti-apoptotic effect on $(M C F-7)$ breast cancer cell line [Asgharzade et al., 2020; Han et al., 2009; Abtin et al., 2018]. Recently, the anti-cancer impacts of different natural components have become the focus of an interesting deal of attention in cancer researches, owing mainly to their potential in prevention of different types of cancer [Dalby et al., 2020; Leto et al., 2020]. Therefore, oleuropein can be effective as a cancer control mechanism by upregulating some proteins and our results demonstrate that Nano oleuropein may exert a protective effect against breast cancer by arresting the cell cycle and inducing apoptosis in these cells confirming the bioactivity of natural compounds and their potential use in cancer therapy.

\section{CONCLUSION}

Synthesis of Nano oleuropein is considered as a successful material in the antitumor agents list and an important factor in the of anti-proliferative direction and induction of apoptosis pathway. Therefore, by inducing upregulation of proteins (PSMD7, CLIC1) by the oleuropein treatment, $M C F-7$ cancer cells play a major role in inhibiting cells growth using anti-proliferation and apoptosis mechanisms. Lack of normal breast cell lines is this research limitation. It is recommended to study and identify other spots and achieve other pathways to inhibit cancer cells by Nano oleuropein treatment.

\section{ACKNOWLEDGMENT}

The author appreciates the efforts of Mrs. Maryam Esmaeilzadeh and respected supervisor Ms. M. Esmailzadeh from Islamic Azad University of Ardabil and Laboratory.

\section{REFERENCES}

Abtin M., Alivand M.R., Khaniani M.S., Bastami M., Zaeifizadeh M., Derakhshan S.M. (2018) Simultaneous downregulation of miR-21 and miR-155 through oleuropein for breast cancer prevention and therapy. Journal of cellular biochemistry, 119(9): 7151-65.

Aktas H.G., Ayan H. (2020) Oleuropein: A potential inhibitor for prostate cancer cell motility by blocking voltage-gated sodium channels. Nutrition and Cancer, 25: 1-0.

Alam M.N., Almoyad M., Huq F. (2018) Polyphenols in colorectal cancer: current state of knowledge including clinical trials and molecular mechanism of action. BioMed research international.

Arndt C., Koristka S., Feldmann A., Bergmann R., Bachmann M. (2018) Coomassie brilliant blue staining of polyacrylamide gels. In Protein Gel Detection and Imaging (pp. 27-30). Humana Press, New York, NY.

Asgharzade S., Sheikhshabani S.H., Ghasempour E., Heidari R., Rahmati S., Mohammadi M., JazaeriA., Amini-Farsani Z. (2020) The effect of oleuropein on apoptotic pathway regulators in breast cancer cells. European Journal of Pharmacology, 886: 173509.

Asgharzade S., Sheikhshabani S.H., Ghasempour E., Heidari R., Rahmati S., Mohammadi M. \& AminiFarsani Z. (2020) The effect of oleuropein on apoptotic pathway regulators in breast cancer cells. European Journal of Pharmacology, 886: 173509.

Avtanski D., Poretsky L. (2018) Phyto-polyphenols as potential inhibitors of breast cancer metastasis. Molecular Medicine, 24(1): 1-7.

Bayat S., Mansoori Derakhshan S., Mansoori Derakhshan N., Shekari Khaniani M., Alivand M.R. (2019) Downregulation of HDAC2 and HDAC3 via oleuropein as a potent prevention and therapeutic agent in MCF-7 breast cancer cells. Journal of cellular biochemistry, 120(6): 9172-80.

Bludau I., Aebersold R. (2020) Proteomic and interactomic insights into the molecular basis of cell functional diversity. Nature Reviews Molecular Cell Biology., 21(6): 327-40.

Dalby M., Cree I.A., Challoner B.R., Ghosh S., Thurston D.E. (2020) The precision medicine approach to cancer therapy: part 1 - solid tumours. Evaluation. 14(47):19.Schättler H., Ledzewicz U. (2015) Optimal control for mathematical models of cancer therapies. Interdisciplinary Applied., 42.

De Matteis V., Cascione M., Toma C.C., Leporatti S. (2018) Silver nanoparticles: synthetic routes, in vitro toxicity and theranostic applications for cancer disease. Nanomaterials, 8(5): 319.

Di Wu M.S., Xue H.Y., Wong H.L. (2017) Nanomedicine applications in the treatment of breast cancer: current state of the art. International journal of nanomedicine, 12: 5879.

Doll S., Gnad F., Mann M. (2019) The case for proteomics 
and Phospho-proteomics in personalized cancer medicine. PROTEOMICS-Clinical Applications, 13(2): 1800113.

Gao H., Niu Y., Li M., Fang S., Guo L. (2017) Identification of DJ-1 as a contributor to multidrug resistance in human small-cell lung cancer using proteomic analysis. International journal of experimental pathology, 98(2): 67-74.

Groh I.A., Chen C., Lüske C., Cartus A.T., Esselen M. (2013) Plant polyphenols and oxidative metabolites of the herbal alkenylbenzene methyleugenol suppress histone deacetylase activity in human colon carcinoma cells. Journal of nutrition and metabolism.

Han J., Talorete T.P., Yamada P., Isoda H. (2009) Antiproliferative and apoptotic effects of oleuropein and hydroxytyrosol on human breast cancer $M C F-7$ cells. Cytotechnology, 59(1): 45-53.

Haymond A., Davis J.B., Espina V. (2019) Proteomics for cancer drug design. Expert review of proteomics. 16(8): 647-64.

Khurshid Y., Syed B., Simjee S.U., Beg O., Ahmed A. (2020) Antiproliferative and apoptotic effects of proteins from black seeds (Nigella sativa) on human breast MCF-7 cancer cell line. BMC complementary medicine and therapies, 20(1):1-1.

Leto G., Flandina C., Crescimanno M., Giammanco M., Sepporta M.V. (2020) Effects of oleuropein on tumor cell growth and bone remodelling: Potential clinical implications for the prevention and treatment of malignant bone diseases. Life Sciences., 30: 118694.

Lu H.Y., Zhu J.S., Xie J., Zhang Z., Zhu J., Jiang S., Shen W.J., Wu B., Ding T., Wang S.L. (2021) Hydroxytyrosol and oleuropein inhibit migration and invasion via induction of autophagy in ERpositive breast cancer cell lines (MCF7 and T47D). Nutrition and cancer, 73(2): 350-60.

Schättler, H., \& Ledzewicz, U. (2015). Optimal control for mathematical models of cancer therapies. New York, NY: Springer, 10, 978-1.

Shamshoum H., Vlavcheski F., Tsiani E. (2017) Anticancer effects of oleuropein. Biofactors, 43(4): 517-28.

Sutradhar K.B., Amin M. (2014) Nanotechnology in cancer drug delivery and selective targeting. International Scholarly Research Notices, .....

Tyanova S., Cox J. (2018) Perseus: a bioinformatics platform for integrative analysis of proteomics data in cancer research. In Cancer systems biology.
Humana Press, New York, NY, pp. 133-148.

Zeidan B.A., Townsend P.A., Garbis S.D., Copson E., Cutress R.I. (2015) Clinical proteomics and breast cancer. The surgeon, 13(5): 271-8.

\section{Müqayisəli proteomiks tətbiqi ilə zeytun meyvəsindən alınan Nano oleuropeinlərlə işlənmiş döş xərçəngi hüceyrələrində zülalların (CLIC1 və PSMD7) ekspressiyası}

\section{Məhəmməd Zəfizadə}

Onanavi Tababat va Hidroterapiya Araşdırma Markazi, Ordəbil Tibb Elmlari Universiteti, Ordabil, Irran

\section{Kamellia Mobasheri}

Biologiya fakültəsi, İslam Azad Universitetinin Ordəbil filiall, Ordəbil, Irran Səyyarə İbadullayeva

AMEA Botanika Institutu, Badamdar şossesi 40, Bakı, AZ1004, Azərbaycan Omin Möhsənzadə

Biologiya fakültəsi, İslam Azad Universitetinin Ordabil filiall, Ordabil, Iran Hoda Sabati

Biotexnologiya və Biologiya Elmi-Tədqiqat Morkəzi, Şahid Çamran Universiteti, Әhvaz, Iran

Döş xərçəngi qadınlar arasında ölümə səbəb olan ən çox yayılmış xərçəng növüdür. Zeytun yağı tərkibindəki antioksidant birləşmələrə görə xərçənglə mübarizədə və onun profilaktikasında təsirli hesab olunur. Bu tədqiqat işində sıxlığ 0 ppm, 300 ppm və 600 ppm olan zeytun yağı Nano oleuropeini iki ölçülü elektroforezi tətbiqi ilə $M C F-7$ hüceyrə xəttindəki protein profilinə təsiri iki-miqyaslı elektroforez və 2D TOF MIFDI istifadə etməklə araşdırılmışdır. Zülalın ekspressiyasını göstərən ləkələrdəki dəyişikliklərin nəticələrinə əsasən, dörd zülal, o cümlədən CLIC1, HSPB 1, PSMD7 və SULT1A2 üzrə 317 ləkədə əhəmiyyətli differensial dəyişikliklər müşahidə edilmişdir ki, bu da Masscot-da 1\%-dən az səviyyə ilə təsdiqlənmişdir. $\mathrm{Bu}$, zülallar antiproliferativ yolunda və apoptoz yollarının induksiyasında mühüm amildir. Buna görə də, oleuropein müalicə ilə zülalların (PSMD7 və CLIC1) ekspressiyasını simullaşdıraraq antiproliferasiya və apoptoz mexanizmləri vasitəsilə MCF-7 xərçəng hüceyrələrinin (SULT1A2 və HSPB1) fəaliyyətinin azalmasında əhəmiyyətli dərəcədə mühüm rol oynayır. Oleuropeinin döş xərçənginin qarşısının alınmasında/müalicəsində faydalılığını sübut etmək üçün əlavə tədqiqat olaraq təqdim edilir.

Açar sözlor: Dunkan testi, elektroforez, LCR test, $M C F$ 7, MALDITOF-TOF, laka 
Экспрессия белков (CLIC1 и PSMD7)

в клетках рака молочной железы с

обработка нано-олеуропеином плодов

оливы с использованием сравнительной

протеомики

\section{Мохаммад Заефизаде}

Исследовательский центр традииионной медииины и гидротерапии, Университет медииинских наук, Ардебиль, Иран

\section{Камелия Мобашери}

Биологический факультет Ардебильского филиала Исламского

Университета Азад, Ардебиль, Иран

\section{Сайяра Ибадуллаева}

Институт Ботаники НАН Азербайджсана, Бадамдарское шоссе 40, Баку, AZ1004, Азербайджан

\section{Амин Мохсензаде}

Биологический факультет Ардебильского филиала Исламского университета Азад, Ардебиль, Иран

\section{Хода Сабати}

Научно-исследовательский центр биотехнологии и биологии, факультет наук, Университет Шахида Чамрана, Ахваз, Иран

Рак молочной железы - самый распространенный вид онкологических заболеваний приводящий к гибели многих женщин. Оливковое масло, имеющее в своем фитохимическом составе антиоксидантные соединения, считается кандидатом в профилактике и борьбе с раком. Было изучено влияние нано-олеуропеина оливкового масла на плотность, а именно обработку 0 ppm, 300 ppm и 600 ppm на профиль белка в клеточной линии $M C F-7$ с использованием двумерного электрофореза и MALDI-TOF-TOF. Peзультаты изменений в пятнах экспрессированного белка показали, что среди 317 пятен четыре белка, включая CLIC1, HSPB1, PSMD7 и SULT1A2, имели значительные дифференциальные изменения, которые были подтверждены с точностью менее $1 \%$ в Masscot. Эти белки являются важным фактором, для антипролиферативного пути и индукции апоптоза. Следовательно, индуцируя стимуляцию экспрессии белков (PSMD7 и CLIC1) с помощью лечения олеуропеином, раковые клетки $M C F-7$ и исползуя механизм антипролиферации и апоптоза, играют важную роль в их сдерживании и значительном снижении экспрессии (SULT1A2 и HSPB1). Применение олеуропеина представлен как способ поддержки индукции пути апоптоз. Исследования олеуропеина необходимы для подтвержения его пользы в профилактике/лечении рака молочной железы.

Ключевые слова: Дункан тест, электрофорез, LCR mест, MCF-7, MALDITOF-TOF, пятно 